\section{Populism, liberal democracy and the ethics of peoplehood}

\section{Fabio Wolkenstein}

Goethe-Universitat Frankfurt am Main, Germany
European Journal of Political Theory 2019, Vol. 18(3) 330-348

(C) The Author(s) 2016

Article reuse guidelines: sagepub.com/journals-permissions DOI: I0.1 I77/|474885 I |667790 I journals.sagepub.com/home/ept

(S)AGE

\begin{abstract}
Populism is widely thought to be in tension with liberal democracy. This article clarifies what exactly is problematic about populism from a liberal-democratic point of view and goes on to develop normative standards that allow us to distinguish between more and less legitimate forms of populism. The point of this exercise is not to dismiss populism in toto; the article strives for a more subtle result, namely, to show that liberal democracy can accommodate populism provided that the latter conforms to particular discursive norms. What the article calls a 'liberal ethics of populism' turns out to be closely bound up with a broader ethics of peoplehood, understood as a way of articulating who 'the people' are in a way that is compatible with liberal-democratic principles of political justification. Such an ethics, concludes the article, inevitably has a much wider audience than populist political actors: its addressees are all those who seek legitimately to exercise power in the name of the people.
\end{abstract}

\title{
Keywords
}

Populism, the people, liberal democracy, justification, partisanship

It is almost a commonplace to say that populism is in tension, or even incompatible, with liberal democracy. Liberal democrats routinely complain that populism is anti-pluralist, the criticism being that it opposes an ostensibly unified people to 'small minorities who are put outside the authentic people' and denies that political power must be responsive to the demands of those minorities in order to be exercised legitimately (Müller, 2014: 485). In a similar vein, they charge populism with being anti-proceduralist, the objection being that it is 'suspicious of electoral representation and the multiparty system', favouring instead direct democratic mechanisms and other strategies that allow an unmediated relationship between the people and government (Saffon and Urbinati, 2013: 451). These properties of populism are said to be at odds with liberal democracy's acceptance of reasonable

\section{Corresponding author:}

Fabio Wolkenstein, Goethe-Universitat Frankfurt am Main, Theodor-W.-Adorno-Platz 6, Frankfurt am Main 60629, Germany.

Email: wolkenstein@em.uni-frankfurt.de 
disagreement and its corresponding commitment to democratic procedures that instantiate equal respect for persons. ${ }^{1}$

Almost equally widespread is however the intuition that some forms of populism are less harmful to a liberal-democratic order than others. It is often said, for example, that an inclusionary left-wing populism which opposes the ' 99 per cent' to a small minority of exploitative capitalist elites (think Bernie Sanders or Podemos) is more consistent with basic liberal commitments than the more exclusionary right-wing populism that identifies immigrants and ethnic minorities as the enemies of the people (think Donald Trump or Viktor Orbán), since it does not target the marginalised but the powerful (cf. Mudde and Kaltwasser, 2013). What kind of normative reasoning might motivate such judgements? Or, put in another way, what shape must populism take in order to be compatible with liberal democracy as we know it today?

My aim in this article is to offer an answer to these questions that is different from those that have been given so far in the literature on the topic. More particularly, I want to ask what a liberal ethics of populism might look like. To that end, I will discuss what is problematic about populism from a liberal-democratic point of view and go on to develop normative standards that allow us to distinguish between more and less legitimate forms of populism - a distinction that appears increasingly important in light of the many different shapes populism takes in the contemporary world.

On the face of it, the framing of the question might seem peculiar. Instinctively we ascribe to populism a certain unruliness, not least because these are the terms in which it presents itself. More often than not, populists are loud and shrill and make use of divisive rhetoric; clearly they defy the liberal-democratic 'rules of the game'. In light of this, one might reasonably wonder whether a liberal 'ethics of populism' could amount to anything more than a high-minded way of saying that populism has no place in a liberal democracy? My objective in what follows is to show that it can. I do not simply want to dismiss populism as a whole, however problematic I find most of its real-world expressions, but strive for a more subtle result, showing instead that liberal democracy can accommodate populism provided that it conforms to particular discursive norms. In short, populism can be compatible with liberal democracy, and this article will show how.

The article divides into three sections. I begin by briefly outlining what I mean by liberal democracy, arguing for a view that sees it as fundamentally about political justification. In the second section, I turn to what I consider the main source of the tension between liberal democracy and populism, namely the particular conceptions of peoplehood populist political projects turn upon. I argue that these are deeply problematic from a liberal-democratic point of view, either legitimating the suspension of political justification or lacking any normative foundation that could guard against contraventions of liberal justificatory norms. In the third section, I consider the question of how the people might be articulated in a way that is compatible with the normative demands of liberal-democratic political justification, offering norms of what I call 'liberal populism' and examples indicating how populists may conform to them. As we shall see, there are indeed 
real-world populists that conform to the norms I propose, and it is important that they be recognised as liberal democrats rather than castigated as 'populists' in some derogatory sense. By way of conclusion, I note that a 'liberal ethics of populism' is inevitably closely bound up with a broader ethics of peoplehood, understood as an answer to the question of how political agents can make claims as to whom political power should be responsive to in a normatively defensible fashion.

Before embarking, a note on terminology is necessary. Populism, as has often been remarked, is an 'essentially contested concept'. 'What exactly it involves remains subject to much scholarly disagreement and debate. Since I do not want to get embroiled in conceptual debates here but assess the concept of populism from a normative point of view, I shall start from what I take to be an ecumenical definition of populism and define it, following scholars like Cas Mudde, JanWerner Müller and others, as 'a particular moralistic imagination of politics, a way of perceiving the political world which opposes a morally pure and fully unified, but ultimately fictional, people to small minorities who are put outside the authentic people'. ${ }^{3}$ Populism so conceived claims to speak in the name of the whole rather than a part and assumes that the whole consists of a unified people. While this definition suffices as a working definition for this article, however, one implication of the discussion that follows is that populism is best understood in terms of a continuum of related political phenomena, rather than in terms of a static ideal type. Indeed, the more liberal variants of populism I will consider towards the end of the article reveal that one can have populism without excessively strong claims about the moral purity and the 'full' unification of the people. Even though some commentators might resist this conclusion, I contend that this is still populism, though arguably a less troublesome form of it. Useful though it is to start from ideal types, these should not distract us from important empirical variations.

\section{Liberalism and political justification}

Understood not as a particular configuration of political institutions but as a normative theory of democratic legitimacy, liberal democracy is essentially about political justification. ${ }^{4}$ This is to say that, in a liberal democracy, political power must be justified to those subject to it in order to be considered legitimate. The move towards justification-centred models of liberalism was inaugurated by John Rawls and Jürgen Habermas, but conceptions of public justification have moved significantly beyond the work of these two authors in recent times (e.g. Dryzek, 2000; Gutmann and Thompson, 1996; Forst, 2012; for an overview treatment, see Chambers, 2010).

Due to the great scholarly interest in the topic, there is much debate about what exactly public justification ought to entail; but it seems that, at a minimum, it must conform to principles of generality and reciprocity. What do these principles stipulate? Reciprocity, explains Forst (2012: 173-174), means that 'in making a claim or presenting an argument, no one may claim a right or resource he denies to others whereby the formulation of the claim must itself be open to questioning and not 
determined by one party only'. Generality, on the other hand, means 'that all those subject to the norms in question must have equal chances to advance their claims and arguments'. ${ }^{5}$ These two principles (or closely related variants of them ${ }^{6}$ ) stand at the centre of contemporary liberal theories of democracy and democratic legitimacy.

Political justification so conceived is usually linked to a model of discursive exchange that sees political agents confront each other in the public sphere, advancing arguments supportive of a given course of action or explaining why it should be altered or repudiated. This model affirms political contestation, indeed sees conflict as inevitable due to the deep pluralism (of values, opinions and preferences) that characterises most liberal societies, and emphasises that in order to accommodate that pluralism, political conflict should be regulated by norms that determine what are its acceptable and unacceptable forms. It leaves ample room for political activism, partisanship and other modes of (more or less) principled adversarialism, yet it places constraints on the public articulation of political proposals. Considerations advanced in the public sphere must instantiate respect for the equality and freedom of those over whom power should legitimately be exercised. ${ }^{7}$ Arguments that lack sensitivity to the normative demands of generality and reciprocity fall short of this demand and are thus impermissible from a liberal point of view.

The public justification model of liberal democracy constitutes the foundation of the liberal ethics of populism I want to develop in what follows. The remainder of the article is concerned with articulating an approach to populism that is broadly compatible with liberal standards of political justification. In order to develop such an approach, however, we must first trace the source of populism's troubled relationship with liberal democracy. We must ask, that is, why there might be a tension between populism and the just-described model of political justification? What is it about populism that jars with principles of generality and reciprocity, or indeed the ideal of political justification more generally?

The source of the tension between populism and liberal democracy, I suggest, is that populist actors typically do not make their claim to representation in such a way that liberal standards of political justification make themselves visible in it, and this has to do with the conception of peoplehood they promote.

Populism, as I have noted at the outset of the article, is predicated on the idea that there exists a morally pure and unified people. This presumed people is the agent in whose name populists seek to exercise power; it is constitutive of any populist political project and serves as the basic legitimating ground for their proposals and ambitions, as in when populists call for closing borders because it be 'the people's will'. And it is in need of justification if the liberal theory of democratic legitimacy I have just sketched is endorsed, for any attempt of defining a bounded collective in the name of whom power should be exercised involves exclusions. And any proposed exclusion must be justified to those affected if the latter are to be treated as free and equal in conformity with the liberal paradigm (cf. Abizadeh, 2008; Näsström, 2007). The problem with most populist conceptions of the people, as we will see, is that they are construed such that justification tout court, or justification in accordance with liberal norms, becomes superfluous. To see this, let us look more closely at the different understandings of the people populists operate with. 


\section{Homogeneity of what? Two concepts of peoplehood}

Who exactly 'the people' are is one of the most challenging problems of political philosophy, sometimes called the 'boundary problem' (Whelan, 1983). Populist actors tend to provide a straightforward solution to that problem, advocating conceptions of peoplehood that draw a bright line between those who belong to the people and those who don't (Kaltwasser, 2014).

If we consider the particular conceptions of the people populists promote, we find two different understandings. Right-wing populists of the kind that gain increasing electoral traction across Northern and Eastern Europe draw on what might be called a cultural-nationalist conception of peoplehood. Left-wing populists like those familiar from Latin American countries or Mediterranean Europe, on the other hand, tend to adopt a contestatory conception of peoplehood. As noted, these definitions of the people lie at the heart of the populist understanding of how power should be exercised in order to be legitimate, thus shaping the nature of their political projects and claims in important ways. From a liberaldemocratic perspective, both hold serious problems.

\section{The people I: The cultural-nationalist account}

Most, if not all, contemporary right-wing populists adopt a cultural-nationalist conception of peoplehood, according to which the boundaries of the people are congruent with the boundaries of the cultural nation. ${ }^{8}$ On this view, the question of who belongs to that cultural nation is treated as pre-politically settled and not open to contestation. The idea is that there are some 'natural' characteristics which establish membership and define a people, language and religion being the classic candidate criteria.

To understand the rationale underlying such an account of the people, it may be useful to briefly turn to one of the foundational texts of modern cultural nationalism, Johann Gottlieb Fichte's Reden an die deutsche Nation. For Fichte, what makes the (German) people a people is shared language: 'Those who speak the same language are already, prior to any human art, by mere nature linked together by a multitude of invisible bonds; they understand each other ... they belong together, and are naturally one, an inseparable whole' (Fichte, [1808] 2005: 267). What becomes apparent in this passage is that, on a cultural-nationalist understanding of peoplehood, what binds a Volk together is not seen as a mere effect of political power but arising spontaneously from shared cultural practices and experiences - from 'organically grown' features of common peoplehood that evolved independent of practices of political contestation, as one European right-wing populist party puts it in one of its programmatic documents (Freiheitliche Partei Österreichs, 2013: 29). Importantly, the cultural-nationalist view of the people also implies that the boundaries of the people and the boundaries of the state should be congruent. As one democratic theorist puts it, 'It is the distinctive feature of cultural-nationalist doctrines that they suppose that the exercise of political power is legitimate only to the extent that it is an expression of, or conforms to, the prepolitical culture of a nation' (Abizadeh, 2008: 868). ${ }^{9}$ 
That this way of thinking about political legitimacy informs contemporary right-wing populism appears, for instance, in the fact that most right-wing populists strongly oppose the idea of politicising the European Union. So Marine Le Pen (2016), the chairwoman of the French Front National, argues that the European Parliament is 'democratic in appearance only, because it's based on a lie: the pretense that there is a homogeneous European people, and that a Polish member of the European Parliament has the legitimacy to make law for the Spanish'. (Note the adjective homogenous in this passage: Le Pen makes no attempt to mask the anti-pluralist presumptions that lie at the heart of her views.)

No doubt, such a view of peoplehood is 'ultimately fictional' (Müller, 2014: 485). One need not tap into radical cultural relativism to see that the question of which features are central to a culture (and who exactly can be said to share these features) cannot be answered once and for all in a non-arbitrary fashion. Selecting candidate criteria for distinguishing a common culture, in other words, is inevitably an instance of political fiat.

From the liberal point of view I am adopting in this article, the problem with the cultural-nationalist account of the people is precisely that it obscures this fundamentally political decision, presenting instead the character and boundaries of the people as natural. This is problematic because it puts the possibility of justifying who the people are in accordance with liberal-democratic justificatory norms out of reach. First and foremost, in claiming a clear demarcation line between who belongs to the people and who doesn't that is not open to revision (because it is natural) and determined unilaterally (by the populists themselves, who claim that they merely articulate a natural fact), the cultural-nationalist account of the people sits uneasily with the principle of reciprocity, which, to recall, requires that political claims must be open to questioning and not determined by one party only. But equally, the proposition that political power must only be responsive to those who belong to a particular cultural group opens the door for a violation of the principle of generality, which stipulates that none of those subject to shared norms and laws must be excluded from the exercise of power. In any pluralist society, where always various different cultural groups are subject to the same source of political authority, such a proposition is bound to lead to unacceptable exclusions. ${ }^{10}$

If conceiving the people as a natural, pre-political entity is likely to lead to normatively insufficient justifications of proposed exclusions, it may also provide a legitimising ground for foregoing the justification of the proposed scope of the people to those affected altogether. This is because naturalising the boundaries of the people diminishes the necessity of giving those boundaries public justification. Why would one have to justify that which is natural and self-evident? Who the people are then becomes something that must simply be revealed and asserted, say, by an enlightened and charismatic leader who speaks for the people as a whole, 'beyond parliament and parties', and so achieves the 'perfect identity of ruler and ruled' (Stanton, 2016: 354).

To be absolutely clear on this, my point is that refusing to justify who the people are is legitimate if we follow the cultural-nationalist view's own internal logic. From the liberal viewpoint, excluding the constitution of the people and its boundaries 
from justificatory demands is always unacceptable, since how boundaries are drawn structures the way in which power is exercised over individuals (Näsström, 2007). But if one thinks, as those endorsing a cultural-nationalist view of the people typically do, that the boundaries of the people are legitimate to the extent that they conform to the purported boundaries of an organically grown cultural nation whose shape is not open to dispute, then asserting the 'fact' that such a nation exists may be sufficient to establish who belongs to the people and who doesn't. This hardly counts as political justification, however, since not even the most permissive conception of justification admits the mere assertion of purportedly indisputable facts. ${ }^{11}$ As noted earlier, the requirement to provide arguments in support of public claims is central to the logic of justification.

But the cultural-nationalist account of the people not only legitimises refusing to justify exclusions to those who suffer from them. It may also legitimise refusing to justify political proposals of different kinds to those included in the people. This is because from the assumption that the people are united in terms of mutual solidarity fostered and sustained by shared characteristics, it is only a short step to the assumption that they are unified also in terms of values and preferences. ${ }^{12}$ When that is the case, clearly there is no need to justify political proposals to pretty much anyone. Neither do exclusions concerning who the people have to be justified to those excluded, nor must policies suggested in the name of the people be justified to those included. ${ }^{13}$ The unified popular will, so the rationale goes, simply has to be revealed - by a charismatic leader or party - and translated into decisions.

If all of this is correct then there are deep-seated tensions between the culturalnationalist view of the people and the liberal-democratic logic of justification endorsed in this article. Because the cultural-nationalist account of peoplehood assumes that who the people are is a natural fact and not subject to contestation, it cannot be made responsive to liberal-democratic justificatory demands and even provides a ground for suspending justification altogether.

\section{The people 2: The contestatory account}

I turn now to the contestatory account of the people, which is typically advocated by left-wing populists. On this account, who the people are is regarded as subject to perpetual re-negotiation in adversarial encounters between different political agents. Contrary to the cultural-nationalist account of the people, this understanding of the people is strongly politicised, proposing as it does that the contours of the people can only be shaped through continuous acts of political mobilisation.

This conception of peoplehood has intellectual roots in the radical-democratic tradition. Some authors belonging in this tradition, notably Ernesto Laclau, have also directly influenced real-world populist movements. ${ }^{14}$ For Laclau (2005), the people ought to be conceived 'as a political category, not as a datum of social structure', not as a 'given group, but an act of institution that creates a new agency out of a plurality of heterogenous elements'. Populists, in his view, must aim at mobilising a particular 'socio-political demand', one that is shared by a large number of people and is not a mere function of (though also not necessarily in 
tension with) their socio-economic location or cultural practices. The unity of the people populists assume is therefore 'simply the result of an aggregation of social demands' (224).

That left-wing populists avail themselves of such an open and flexible conception of peoplehood becomes apparent in their trademark efforts to mobilise a broad coalition of individuals against the political and capitalist establishment. As Cristobal Kaltwasser (2014) argues, in assessing different populist parties' electoral strategies: left-wing populists typically seek to fashion the people in terms of the 'plebs', alluding 'to the multitude of ordinary folks vis-à-vis the elite' (479-480). This notion of the people provides an opportunity for individuals across society to identify with the people as a whole, for it allows them to use a grievance to identify themselves as the authentic embodiment of the people - in contrast to those other people, who are responsible for that grievance. Thus, Pablo Iglesias, SecretaryGeneral of the Spanish left-wing populist party Podemos, highlights that his party's strategy of mobilisation 'allowed these victims [of austerity politics] subaltern layers, above all the impoverished middle classes — to identify themselves as such and to visualize, through the form of a new "us", the "them" of their adversaries: the old [political] elites' (Iglesias, 2015: 17).

It is tempting to embrace the contestatory conception of the people advocated by left-wing populists as being more consistent with liberal demands of generality and reciprocity than the cultural-nationalist one endorsed by right-wing populists. After all, it eschews the depoliticising moves we have rightly criticised in the cultural-nationalist account of the people, acknowledging that the question of who the people are is subject to an ongoing public process of claim and counter-claim. And to acknowledge this is to acknowledge that arguments concerning the scope of the people require some sort of justification. In connection with this, the contestatory account of the people also resists the exclusionary and deterministic implications of the cultural-nationalist understanding of peoplehood we have examined earlier, allowing instead for wideranging alliances of citizens troubled by similar predicaments. All of this appears to make the contestatory conception of the people more acceptable from a liberal point of view, leading some scholars to celebrate left-wing populism as the most promising answer to right-wing populism (Mouffe, 2013; also cf. Mouffe, 2000). ${ }^{15}$

But the temptation to endorse the left-wing populist contestatory account of the people must be resisted. This is because in fully decoupling the question of the people from ethical concerns about political conflict, it fails to provide any norms guiding the articulation of who the people are (and of political commitments that are proposed in the name of the people); like White and Ypi (2017) I think that " "over-politicising" the question of peoplehood' holds the risk of becoming 'insensitive to the different ways claims are advanced in the public sphere'. On the liberal-democratic view I am adopting here, this is problematic: definitions of peoplehood are to some extent always exclusionary, and all claims to exclusion must be articulated in such a way that the principles of generality and reciprocity make themselves visible in them.

The risks of an entirely norm-free conception of the people are also sensibly palpable in Laclau's theory of populism, which informed so many real-world 
left-wing populist projects. Critics of Laclau's approach have rightly pointed out that his understanding of the people as 'an act of institution that creates a new agency out of a plurality of heterogenous elements' (2005: 224) 'directs our attention away from what can be oppressive about populist movements and insulates them from criticism' (McKean, 2016). In his astute critique of Laclau's book On Populist Reason, for example, Benjamin McKean (2016) argues that Laclau's allegedly inclusive view of peoplehood is vulnerable to exclusionary tendencies since it overlooks that 'some subjects are constituted with a racial identity that prevents their unmediated identification with the people as a whole'. Here again, the takeaway is that without norms that regulate which answers to the question of the people are normatively acceptable and which aren't, the door is wide open to the kind of arbitrarily exclusionary rhetoric liberals - and indeed also left-wing populists - typically disavow.

The norm insensitivity of contestatory conceptions of peoplehood becomes even more troubling when left-wing populists claim, analogous to some right-wing populists, that the people do not disagree about policies and the common good but are unified also in terms of their values, interests and preferences. For when that is the case, the same problem arises that we have encountered in the discussion of the cultural-nationalist account of the people, only for different reasons: policies suggested in the name of the people must not be justified to the people, as they are taken to reflect the people's presumedly unified will. Arguably a contestation view of the people is less susceptible to such a static understanding of collective preferences and demands, since it is based on the idea that the people must continually mobilised; but once efforts at mobilisation succeed and a stable following has been created, the danger of unduly overstating preferential homogeneity is very real. Thus, even the most 'progressive' populism can create a heavy anti-liberal pull akin to that of cultural-nationalist conceptions of the people.

The conclusion to take from examining these arguments is accordingly that, from a liberal-democratic point of view, contestatory conceptions of peoplehood are deeply problematic. Guided by the ambition to recover and mobilise the people's potential for revolutionary action, they lack concern for liberal norms of political justification.

\section{Is liberal populism possible?}

Up until this point, we have seen that the conceptions of the people advocated by (both left-wing and right-wing) populists are insufficient from a liberal-democratic viewpoint. The question to which I now want to turn my attention is how a conception of peoplehood that is responsive to norms of generality and reciprocity might look. Fashioning claims as to who the people are in conformity with liberal justificatory norms is a challenging task, since what has to be justified are exclusions that are not natural or inevitable. As will become clear, however, it is indeed possible to answer the question of peoplehood in way that is consistent with the demands of political justification. I will first discuss two possible liberal responses 
to the problem at stake and then advance a third, alternative, answer that I deem more promising than the others.

\section{The people as process}

If the problem with populist conceptions of peoplehood is their insufficient responsiveness to liberal normative demands, the way forward is to find a way of making these conceptions of the people more sensitive to the significance of these demands. How might this be achieved? In a recent paper, White and Ypi (2017) suggest what may be called a proceduralist strategy, arguing that it suffices to subject competing conceptions of peoplehood, including populist ones, to partisan contestation. For in the public process of claim and counter-claim, partisan agents will be compelled to advance their interpretation of who the people are in accordance with principles of generality and reciprocity. The reason why this is so is that they are required 'to convince others of the appeal of their commitments' and to take 'institutional steps to advance their realisation in a way that is publically legitimated'. ${ }^{16}$ In short, the partisan process effectively imposes constraints on how claims concerning the scope and nature of the people can be articulated in the public sphere - ones that help make those claims responsive to liberal democracy's normative demands.

But even if we grant that the constraints of party competition ideally work to that effect, White and Ypi's argument overlooks that populist political actors usually seek to defy the logic of traditional partisan contestation and deliberation. Such is the rationale of their activities. Indeed, much of the anti-establishment rhetoric of contemporary populism targets party democracy with its norms, procedures and the limits it places on what can be said in public and what can be done within the parameters set by existing (liberal) political institutions (think for example of the intensity with which many right-wing populists oppose 'political correctness'). As Müller (2016) argues, in their self-understanding, populist parties are not normal political parties but rather 'a "front (National)" or 'a "movement", (57). Consistent with this, their political strategy is typically one of transgressing, rather than complying with, established norms of political contestation and discourse. This extends to the way in which political justification is delivered: routinely dominant discursive norms are breached in order to show that one differs from the mainstream and in order to attract public attention.

If this is correct, it is questionable whether we can blindly impute to populist agents a motivation for compliance with liberal discursive norms in the partisan process of contestation. White and Ypi (2017) stress that 'even undesirable forms of partisanship must articulate their claims in public and by appeal to generalizable principles' once they enter partisan competition, but it is by no means clear that they really must do so. Moreover, even if populists appeal to generalisable principles, this need not mean that they articulate their claims in conformity with our twin norms of generality and reciprocity. As we saw, for example, rightwing populists may make claims about a cultural nation that are intended as generalisable, yet jar with generality and reciprocity as understood by liberal democrats, as they propose unalterable and permanent exclusions. 
At one point in their argument, White and Ypi (2017) appear to acknowledge this problem, conceding that "there is nothing in [the partisan] process ... to guarantee that narrowly exclusionary tendencies do not prevail'. But rather than accepting that this implies that that process cannot safeguard liberal democracy against such tendencies, they argue that this is simply 'one of the risks associated with the openendedness of partisan politics', and go on to note that 'even if morally dubious', populist attempts to exclude from the people those who liberal democrats might want to see included 'may be politically instructive' inasmuch as they 'alert us to the pressing need to promote counter-perspectives and act as a provocation to do so'. Without disputing that the promotion of counter-perspectives on who the people are is important when dealing with populist agents, this conclusion offers little in the way of a satisfactory answer to the question of how populist conceptions of peoplehood can be made more responsive to liberal ideals of justification. Liberal democrats committed to the ideal of public justification would, therefore, do better not to put too much faith in the procedural solution proposed by White and Ypi. Subjecting populist conceptions of peoplehood to contestation in public political disputes is by all means important, but there is no reason to think that contestation leads populists to renounce their illiberal commitments.

\section{Expansionism: The people unbounded}

Let us consider a second possible liberal response to the problem at stake. This argues that the only conception of peoplehood that is truly faithful to liberaldemocratic demands of political justification is a cosmopolitan conception that sees the people as in principle unbounded. This position, associated perhaps most prominently with Arash Abizadeh $(2008,2012)$, contends that justification for the boundaries of the people (and the policies proposed in the name of the latter) is not only owed to those included in but also to those excluded from that people, which is to say that it is owed to the whole of humanity.

How do we get to this result? Simply by accepting that, insofar as liberal principles of justification are intended to respect the equality and freedom of those over whom power is exercised (hence the principles of generality and reciprocity, see above), and insofar as excluding individuals from the people means exercising power over them, there can be no boundary to the constituency to which arguments to the effect of defining the people are addressed. Abizadeh (2012: 875) calls this the externality problem of political justification. Applied to real-world politics, the implication is that any view of whom political power should be responsive to ought to be justified not only vis-à-vis the members of a particular political community but vis-à-vis the world's population as a whole.

This expansionist approach to peoplehood is no doubt consistent with the normative impetus of the liberal model of political justification that forms the basis of the present article, and it offers clear prescriptions as to how the people ought to be operationalised by liberal democrats. However, even if there may be much to sympathise with in such a cosmopolitan view of the people, it also provides a perspective that is too inclusive to be practically feasible. Indeed, it is very difficult to see 
how political claims could be justified to the population of the world at large. As Robert Goodin (2008: 148) puts it, 'any much extended demos is conversationally very problematic', not least because of language barriers and the limits of communicative technology. Constant violations of liberal principles inevitably ensue: it would simply not be possible for political agents to comply with the ideal of political justification in any satisfying way, neither in the ideal world we might wish to inhabit nor in the real one we can expect to encounter. Thus, if it is to be a plausible political ideal that is capable of inspiring compliance, a liberal-democratic understanding of peoplehood cannot be expansionist in the just-described sense.

Of course, to say that such a cosmopolitan conception of peoplehood is unworkable is not to deny that some form of it - presumably a more narrow one than Abizadeh's - could not over time gain public legitimacy as a normatively desirable understanding of whom political power should be accountable to. Indeed, it is possible to imagine that a cosmopolitan view of the people might become more widely accepted at some point in time, leading to a concomitant shift in the design of political institutions. Presumably this would require that cosmopolitan-minded political agents advance this view of the people politically, both in the domestic sphere and through coordinating internationally with like-minded others (cf. Ypi, 2012). Nonetheless, because of its lack of feasibility, both in the world as we know it and in the most favourable circumstances we might imagine, the cosmopolitan account fails to furnish an appealing normative foundation for approaching the question of peoplehood.

\section{Normative foundations of an alternative account}

We have seen that both the procedural and the expansionist approaches to the question of how articulations of the people must look in order to be compatible with liberal norms are unpersuasive. In reflecting on the shortcomings of these strategies as well as on the notions of the people we have discussed earlier in the article, however, one already gets the first glimpse of the features a conception of peoplehood that can be justified in accordance with liberal-democratic norms must exhibit. So let me spell these out. In short, my suggestion is that any claim concerning who the people are that marks itself off from conceptions of peoplehood that are undesirable from a liberal-democratic point of view must (a) not turn upon pre-political grounds of popular unity, (b) exhibit sensitivity to the externality problem and (c) remain responsive to demands for justification from outside the people. These normative criteria do not prescribe any particular boundaries for the people, but they declare impermissible conceptions of peoplehood which turn upon presumed natural facts or are narrowly exclusionary in their implications and so unjustifiable in terms of generality and reciprocity.

a. Earlier we have seen that views of the people that appeal to pre-political grounds are especially problematic. To recall: if it is assumed that who belongs to the people can be established through an analysis of ostensibly 'natural' features that are shared by a particular collective of individuals, for example 
a common language, this implies an understanding of the people not as a political claim requiring public argumentative defence but as a fact to be revealed and asserted. From a liberal-democratic point of view, this is suspect. Not only does it obscure the fact that any answer to the question of the people involves political decisions concerning collective belonging and concomitant value choices. Even more pertinently, it naturalises the people in a way that precludes the possibility of contestation and revision. If we follow this line of thought, we are easily led to argue that particular boundaries of the people need not be justified or legitimised at all. This clearly involves a failure to respect the equality and freedom of those over whom power is supposed to be exercised in a legitimate fashion, since they might reasonably disagree and so should be capable of challenging that particular idea of the people in a public process of claim and counter-claim. Thus, to be defensible within the normative framework of liberal democracy, political articulations of peoplehood must at all costs avoid resorting to pre-political grounds as a foundation for their legitimacy.

b. The requirement that pre-political grounds should not be appealed to in legitimising conceptions of peoplehood strictly rules out the cultural-nationalist doctrine right-wing populists typically endorse, suggesting instead a more flexible view of the people. However, not just any more flexible conception of peoplehood will do. If we accept the normative requirements of political justification, then any permissible understanding of the people must be sensitive to what we have earlier encountered under the heading of Abizadeh's 'externality problem'. To recall, this is that 'enforced decisions about who is granted and who is denied membership and political rights' necessarily involve the exercise of political power 'over both insiders and those whom the boundary picks out as outsiders' (Abizadeh, 2012: 875). To give a conception of peoplehood public justification in a normatively defensible fashion demands recognising this problem: the problem, that is, that outsiders may be affected by suggested boundaries as much as insiders, and that this triggers a requirement of justifying those boundaries to both insiders and outsiders. Now, as I said, if this is interpreted to mean that claims as to who the people are have to be justified to the whole of humanity, we face an insurmountable task. Though conceptually coherent, this interpretation of the externality problem lacks persuasive force. A more plausible interpretation, I suggest, takes the externality problem to mean that the proposed boundaries of the people ought to be justified, at the very least, to those outsiders who are most directly and immediately affected by them most uncontroversially perhaps those 'outsiders' who are formally recognised as members of a polity but excluded from the people in connection with a particular populist political strategy (for example when left-wing populists claim that the capitalist elite does not belong to the people, or when rightwing populists claim that citizens with foreign backgrounds do not belong to the people).

c. To be sure, how large the circle of outsiders offered justification for their exclusion from the people should ultimately be rendered is an extremely difficult 
question, one that is impossible to settle once and for all. So far I have rejected expansionist views that regard the scope of the people as necessarily global, and suggested that justification is owed, at the very least, to those outsiders that are most directly and immediately affected by the exclusions entailed by any conception of peoplehood. The final norm, which is closely related to the previous one but distinct in focus, adds to this that a defensible conception of peoplehood must be kept responsive to demands for justification from outside the people. It emphasises, that is, that outsiders - within a given polity or outside of it - may legitimately insist that their exclusion from the people should be justified to them, and that their request ought not simply be ignored. ${ }^{17}$ To allow for such responsiveness, the question of who belongs to the people must, consistent with (a), be open to continual renegotiation, for to show respect for the equal freedom of those subject to political power in a liberal democracy is to acknowledge that any publicly articulated claim may be subject to reasonable disagreement. Together with (b), this requirement of responsiveness to actual justificatory demands usefully enables us to sidestep the problems that arise when we conceive the people in unbounded terms while retaining our commitment to public justification.

With these three norms in hand, it is possible to imagine in what ways populist political actors could shape their favoured conception of the people so as to render it justifiable in conformity with liberal-democratic principles. Conceivably conceptions of peoplehood in which the just-discussed norms make themselves visible would resemble those which so-called civic nationalists tend to promote. A civic nation, as one author puts it, 'need not be unified by commonalities of language or culture'; it suffices that there is a 'disposition on the part of citizens to uphold their political institutions, and to accept the liberal principles on which they are based. Membership is open to anyone who shares these values' (Stilz, 2009: 257). This is a distinctively liberal vision of the people, so it is no surprise that the norms we have distinguished point towards it.

An emblematic example of such a view of peoplehood is found in Scottish nationalism. Scottish nationalism, which has witnessed a renaissance in the past few years and has genuine populist appeal, does not rest on a pre-political conception of the people, and, not least because Scotland is part of a Union with England, Wales and Northern Ireland, is particular responsive to justificatory demands vis-àvis those excluded. Perhaps unlike most nationalisms, it rests on the presumption that boundaries between the Scottish people and those of England, Wales or Northern Ireland cannot be taken for granted but must be articulated and justified as plausible in the context of a broader egalitarian project. That egalitarian political project, grounded in a strong commitment to defend the welfare state, is sometimes in fact regarded as the main justification for Scottish nationalism in the first place. Indeed, on one widespread interpretation, Scottish nationalism is primarily 'an instrumental device for the realisation of a more egalitarian society' (Jackson, 2014: 52). This became apparent in the campaign preceding the 2014 Scottish referendum on independence: for the Yes campaign, led by the declaredly nationalist and 
populist Scottish National Party (SNP), 'leftist arguments', in particular a strong 'welfarist commitment', became 'central to its expression as a political movement' (White, 2015: 107). In sum, in Scottish nationalism identification with a specific political project is largely substituted for identification with other 'carriers' of commonality, such as culture or class. So claims about the scope of the people are rendered as distinctively political claims that require justification to those affected; and because of the obvious ways in which Scotland is implicated in a larger political unit, it is accepted that such justification must be addressed to outsiders, too.

One may also plausibly imagine articulations of who the people are that take an entirely different tack. One might think, for example, of claims concerning the scope of the people that neither presuppose shared political institutions nor shared cultural belonging, possibly voiced in the pursuit of creating common institutions in the future. Less abstractly perhaps, one may think of claims to peoplehood that concern a large, heterogenous collective united only by an institutional minimum, as in the Swiss idea of Willensnation (i.e. a nation united by a common will to form a whole), where a multilingual demos with pronounced internal differences is held together by little more than a unified voting space (Lacey, 2013). Such conceptions of peoplehood, I contend, transcend standard civic nationalism but could in principle be justified in terms consistent with the norms suggested above, not least because they reject pre-political grounds of popular unity and leave room for the inclusion of a variety of individuals into a larger people. So the norms of ethical populism need not always or necessarily lead to civic nationalist conceptions of the people, but may leave space for a number of different views as to who the agent is in whose name power must be exercised in order to be legitimate.

What these reflections reveal is that there are certain - real and hypothetically imaginable - populist political projects that can be defended in conformity with the normative demands of political justification promoted by liberal democrats. If the arguments of this article are endorsed, it is important that these projects are recognised as compatible with liberal democracy rather than being reproached as populist in a derogatory sense. Liberal populism is not a contradiction in terms but a very real possibility, even if we may not encounter it often in contemporary democracies.

\section{Conclusion}

The above discussion indicates that an ethics of populism is closely bound up with a broader ethics of peoplehood. Articulating such an ethics, as we have seen, involves searching for an answer to the question of how the people in whose name political agents claim to speak can be articulated in a fashion that is normatively defensible in a liberal democracy, understood as a regime in which political power must be justified to those subject to it in conformity with principles of generality and reciprocity. The answer I have suggested - namely that a defensible conception of the people must avoid appealing to pre-political grounds of popular unity, be sensitive to the externality problem and responsive to demands for justification from outside the people of course has a much wider audience than populist political actors. Its addressees are all those who seek legitimately to exercise power in the name of the people. 
However, it is populists, both on the left and on the right, who put the people at the centre of the argumentative strategies they employ in order to legitimise their political proposals. For this reason, they are the first and most natural addressee of an ethics of peoplehood, and were the main focus of this article.

Importantly, even if the larger part of real-world populists are not receptive to normative considerations of the kind advanced in this article, and there is plenty of reason to believe that they care little about the ethics of political contestation, having norms of 'ethical populism' at our disposal provides us with something valuable. They provide a starting point for a normatively grounded critique of populist practice, allowing us to distinguish more clearly between those conceptions of peoplehood that are appropriate in a liberal democracy and those which aren't. If we do not want to exempt populist claims from sustained normative scrutiny - and if we do not want to content ourselves with the blunt assertions of moral superiority liberals often resort to when confronting populists either - then a foundation of this kind is crucial. But the value of the proposed norms is not restricted to their critical power. Being better able to articulate what's wrong with populism may also inform alternative political projects, ones that confront the populists of our age with a more liberallyminded conception of the people as united in diversity.

\section{Declaration of conflicting interests}

The author(s) declared no potential conflicts of interest with respect to the research, authorship, and/or publication of this article.

\section{Funding}

The author(s) received no financial support for the research, authorship, and/or publication of this article.

\section{Notes}

1. On these features of liberal democracy, see e.g. Valentini (2012).

2. See e.g. the discussions of the concept in the volume Populism and the Mirror of Democracy, edited by Francisco Panizza (2005).

3. This particular definition is Müller's (2014: 485). Cas Mudde, in his classic paper 'The Populist Zeitgeist' (2004), similarly defines populism as

a thin-centred ideology that considers society to be ultimately separated into two homogeneous and antagonistic camps, "the pure people" and "the corrupt elite," and which argues that politics should be an expression of the volonté générale (general will) of the people. (543)

Like Müller's definition, this view also stresses that populism is a moral set of ideas based on a 'Manichean' distinction between the elite, which is seen as a pathological entity, and the people, who are depicted as a homogeneous and virtuous community.

4. Note: even though I am focusing here only on the justificatory dimension of liberal democracy, I am not denying that populists might engage in practices that are troublesome from a liberal-democratic point of view but do not directly have to do with the justificatory dimension. As one anonymous reviewer rightly pointed out, it is in principle possible to 
imagine populists who speak like good liberal democrats while engaging in practices that are hard to reconcile with this, for example constitutional interventions. Yet these seem to be rare cases, since populist are seldom in a position of power where they can intervene directly in the institutional architecture of liberal democracy. Viktor Orbán and his Fidesz party might qualify as populists who are sufficiently empowered to conduct constitutional interventions, but they rarely speak like good liberal democrats, either.

5. Forst often tries to distinguish his own approach, which centres on a basic 'right to justification', from liberal approaches (2012: ch. 7). But even if this distinction carries some plausibility if liberalism is taken to refer to Rawls or Habermas, it loses its meaning once we consider the way in which recent (i.e. post-Rawlsian and post-Habermasian) liberal theory has developed. As Chambers (2010) rightly points out, in light of these developments Forst's approach can reasonably be seen as falling within the purview of liberal approaches to political justification.

6. Sometimes 'reasonableness' is substituted for generality, though it arguably reflects largely identical normative impulses (see Chambers, 2010: 898-900).

7. Though liberal theorists only seldom acknowledge partisanship's significance as a practice of democratic contestation. For exceptions, see e.g. Muirhead and Rosenblum (2006) and White and Ypi (2011).

8. I borrow the term 'cultural-nationalist' from Abizadeh (2012).

9. Notice that several popular contemporary political theorists also endorse a culturalnationalist understanding of peoplehood; see e.g. David Miller (2009) or Walzer (1983).

10. Notice first that it may be possible to answer the question of whether the culturalnationalist account of the people can be justified in accordance with liberal-democratic norms in the affirmative if one adopts a very permissive account of public justification, say one on which public justification only demands 'accessible' or 'intelligible' reasons. If we assume that justification has to conform to the principles of generality and reciprocity, however, as I do here, it is difficult to see how such efforts at justification might succeed. Notice second that, when it comes to the exclusionary tendencies of particular cultural-nationalist conceptions of the people, in practice much depends on the radicalness of a given populist project and the strength of its claims about cultural unity (for example, several right-wing populist parties across Europe, such as the Austrian FPÖ, recognise some long-standing ethnic minorities as legitimate members of the cultural nation). Such empirical variations notwithstanding, because it tends to naturalise and thus reify existing exclusions the cultural-nationalist answer to the question of peoplehood is always difficult to justify in a way that is defensible in a liberal democracy.

11. Note that this tendency to suspend justification plagues cultural nationalism more generally, beyond political practice (Abizadeh, 2012). Even within the academy, proponents of cultural nationalism tend to simply conjure the existence of pre-political historical peoples rather than treating their boundaries as open to competing interpretations and thus requiring justification (cf. Miller, 2009, 2012).

12. Claiming that the people are unified in this second, 'thicker' sense is in fact a staple of right-wing populist rhetoric. In the public discourse of Viktor Orbán's Fidesz party, for example, 'the category of "nation," or "people," rarely appears as composed of diverging interests' (Enyedi, 2016: 11).

13. Note: from this it also follows that there is no need for 'intermediary bodies' such as political parties, who confront each other in the parliamentary process to negotiate collective decisions that strike a balance between different legitimate claims. This is what I have in the introduction to the article called populism's anti-proceduralist tendency. See Urbinati (2015). 
14. For example the Spanish left-wing populist party Podemos and the Greek Syriza party. See Kioupkiolis (2016) and McKean (2016).

15. Though Mouffe's position is often interpreted in opposition to liberal-democratic theories, it may be read as a post-foundationalist liberal theory, due to its recourse to basic liberal principles of freedom and equality. Scholars who have recognised and discussed the affinities between Mouffe's agonism and liberal theories of democracy include Ebeling (2014) and Knops (2007).

16. This idea appears already in Sartori's classic work Parties and Party Systems ([1976] 2005), where it is suggested that 'if the constraints of the system are operative' (22), the kind of political justification parties discharge will eschew appeals to overly narrow constituencies or factional self-interest.

17. To take a real-world example, imagine Slovak citizens exhorting the Hungarian government to justify their 2012 decision to extend Hungarian citizenship to Slovaks of 'ethnic' Hungarian origin. On that decision, see BBC News (2012).

\section{References}

Abizadeh A (2008) Democratic theory and border coercion: No right to unilaterally control your own borders. Political Theory 36(1): 37-65.

Abizadeh A (2012) On the demos and its kin: Nationalism, democracy, and the boundary problem. American Political Science Review 106(4): 867-882.

BBC News (2012) Slovaks retaliate over Hungarian citizenship law. Available at: http:// www.bbc.com/news/10166610 (accessed 12 June 2016).

Chambers S (2010) Theories of political justification. Philosophy Compass 5(11): 893-903.

Dryzek J (2000) Deliberative Democracy and Beyond: Liberals, Critics, Contestations. Oxford: Oxford University Press.

Ebeling M (2014) Wenn der Spaten sich zurückbiegt: Mouffes Wittgensteinianische Analyse radikalen Dissenses und darüber hinaus. Zeitschrift für Politische Theorie 5(2): 234-251.

Enyedi Z (2016) Paternalist populism and illiberal elitism in Central Europe. Journal of Political Ideologies 21(1): 9-25.

Fichte JG ([1808] 2005) In: Fuchs E, Gliwitzky H, Lauth R, et al. (eds) Gesamtausgabe der Bayerischen Akademie der Wissenschaften: Werke 1808-1812, Vol. I, 10. Stuttgart-Bad Cannstatt: Frommann-Holzboog.

Forst R (2012) The Right to Justification. New York, NY: Columbia University Press.

Freiheitliche Partei Österreichs Handbuch Freiheitlicher Politik: Ein Leitfaden fuür Fuührungsfunktionaüre und Mandatstraüger der Freiheitlichen Partei Oüsterreichs. Wien: FPÖ-Bildungsinstitut.

Goodin RE (2008) Innovating Democracy: Democratic Theory and Practice After the Deliberative Turn. Oxford: Oxford University Press.

Gutmann A and Thompson D (1996) Democracy and Disagreement. Cambridge, MA: Harvard University Press.

Iglesias P (2015) Understanding Podemos. New Left Review 93: 7-22.

Jackson B (2014) The political thought of Scottish nationalism. The Political Quarterly 85(1): $50-56$.

Kaltwasser CR (2014) The responses of populism to Dahl's democratic dilemmas. Political Studies 62(3): 470-487.

Kioupkiolis A (2016) Podemos: The ambiguous promises of left-wing populism in contemporary Spain. Journal of Political Ideologies 21(2): 99-120. 
Knops A (2007) Agonism as deliberation - On Mouffe's theory of democracy. Journal of Political Philosophy 15(1): 115-126.

Lacey J (2013) Must Europe be Swiss? On the idea of a voting space and the possibility of a multilingual demos. British Journal of Political Science 44(1): 61-82.

Laclau L (2005) On Populist Reason. London: Verso.

Le Pen M (2016) After Brexit, the People's spring is inevitable. New York Times, 28 June 2016. Available at: http://www.nytimes.com/2016/06/28/opinion/marine-le-pen-afterbrexit-the-peoples-spring-is-inevitable.html?smid $=\mathrm{fb}$-nytimes\&smtyp $=$ cur\&_r $=5$, (accessed 29 June 2016).

McKean BL (2016) Toward an inclusive populism? On the role of race and difference in Laclau's Politics. Political Theory 44(6): 797-820.

Miller D (2009) Democracy's domain. Philosophy and Public Affairs 37(3): 201-228.

Miller D (2012) Territorial rights: Concept and justification. Political Studies 60(2): 252-268.

Mouffe C (2000) The Democratic Paradox. London: Verso.

Mouffe C (2013) Agonistics: Thinking the World Politically. London: Verso.

Mudde C (2004) The populist zeitgeist. Government and Opposition 39(4): 542-564.

Mudde C and Kaltwasser CR (2013) Exclusionary vs. inclusionary populism: Comparing contemporary Europe and Latin America. Government and Opposition 48(2): 147-174.

Muirhead R and Rosenblum N (2006) Political liberalism vs. "the great game of politics": The politics of political liberalism. Perspectives on Politics 4(1): 99-108.

Müller JW (2014) 'The people must be extracted from within the people': Reflections on populism. Constellations 21(4): 483-493.

Müller JW (2016) Was ist Populismus? Ein Essay. Frankfurt am Main: Suhrkamp.

Näsström S (2007) The legitimacy of the people. Political Theory 35(5): 624-658.

Panizza F (2005) (ed) Populism and the Mirror of Democracy. London: Verso.

Saffon MP and Urbinati N (2013) Procedural democracy, the bulwark of equal Liberty. Political Theory 41(3): 441-481.

Sartori G ([1976] 2005) Parties and Party systems: A Framework for Analysis. Colchester: ECPR Press.

Stanton T (2016) Popular sovereignty in an age of mass democracy: Politics, parliament, and parties in Weber, Kelsen, Schmitt and beyond. In: Bourke R and Skinner Q (eds) Popular Sovereignty in Historical Perspective. Cambridge: Cambridge University Press, pp.320-358.

Stilz A (2009) Civic nationalism and language policy. Philosophy and Public Affairs 37(3): 257-292.

Urbinati N (2015) A revolt against intermediary bodies. Constellations 22(4): 477-486.

Valentini L (2012) Justice, disagreement and democracy. British Journal of Political Science 43(1): $177-199$.

Walzer M (1983) Spheres of Justice: A Defense of Pluralism and Equality. New York: Basic Books.

Whelan F (1983) Democratic theory and the boundary problem. In: Pennock JR and Chapman JW (eds) NOMOS 25: Liberal Democracy. New York, NY: New York University Press, pp.13-47.

White J (2015) When parties make peoples. Global Policy 6(1): 106-114.

White J and Ypi L (2011) On partisan political justification. American Political Science Review 105(2): 381-396.

White J and Ypi L (2017) The politics of peoplehood. Political Theory 45(4): 439-465.

Ypi L (2012) Global Justice and Avant-Garde Political Agency. Oxford: Oxford University Press. 